\title{
The Cretaceous Period of Weather Similar to the Present One and Its Diverse "Conchostracan" Fauna
}

\author{
Oscar F. Gallego ${ }^{*}$, Mateo D. Monferran1, Victoria C. Jiménez¹, Iracema A. Zacarías ${ }^{1}$, \\ Claudia Armella², Diego Silva Nieto ${ }^{3}$, Nora G. Cabaleri² \\ ${ }^{1}$ Centro de Ecología Aplicada del Litoral (CECOAL-CONICET-UNNE) and Área Ciencias de la Tierra, Departamento de Biología, \\ Corrientes, Argentina \\ ${ }^{2}$ Instituto de Geocronología y Geología Isotópica (INGEIS-CONICET-UBA), Ciudad Universitaria, Buenos Aires, Argentina \\ ${ }^{3}$ Servicio Geológico Minero Argentino, Buenos Aires, Argentina \\ Email: *ofgallego@live.com.ar
}

How to cite this paper: Gallego, O.F., Monferran, M.D., Jiménez, V.C., Zacarías, I.A., Armella, C., Nieto, D.S. and Cabaleri, N.G. (2019) The Cretaceous Period of Weather Similar to the Present One and Its Diverse "Conchostracan" Fauna. Open Journal of Geology, 9, 704-706.

https://doi.org/10.4236/ojg.2019.910080

Received: August 17, 2019

Accepted: September 22, 2019

Published: September 25, 2019

Copyright $\odot 2019$ by author(s) and Scientific Research Publishing Inc. This work is licensed under the Creative Commons Attribution International License (CC BY 4.0).

http://creativecommons.org/licenses/by/4.0/

\begin{abstract}
Cretaceous System is widely represented in South America from northeast Brazil to southern Patagonia Argentina. It is characterized by having been a relatively warm climate, with rainfall and marked seasonality which allowed the development of the "conchostracan" populations.
\end{abstract}

\section{Keywords}

Cretaceous, Climate, Fossil Record, South America

\section{Introduction}

The Cretaceous Period was a period with warm climate [1], with increasingly high sea levels in the epicontinental seas. The average global temperature was near to $18^{\circ} \mathrm{C}$ [2]. Despite the greenhouse character of the period, the cooling trend towards the Maastrichtian and the $116 \mathrm{Ma}$ "cold snap" triggered the interest in possible continental Cretaceous glaciations [3].

\section{Cretaceous Climate and Bearing "Conchostracan" Faunas}

In the Lower Cretaceous, the monsoon circulation of the Pangea culminated, due to the opening of the Atlantic Ocean [4]. The cool interval in the Early Cretaceous is followed by warming lasting until the late Albian [5]. In the continental regions there were changes in atmospheric circulation. Wetter conditions developed and paleoprecipitations increased in tropical areas [6]. Oceanic and 
continental data suggest equatorial paleotemperatures similar to the present-day [7]. This time was characterized by the presence of areas with prevailing microclimates. In intracratonic basins (e.g. northeast Brazil), the climate was arid with warm-hot temperatures. This type of arid climate, with heavy rainfall, generated favorable seasonal conditions for the development of a diverse "conchostracan" fauna. Wind patterns shew seasonality leading to more extreme climates over the continents. During the Upper Cretaceous warm weather prevailed, with greenhouse periods, globally averaged temperatures were $6^{\circ} \mathrm{C}-14^{\circ} \mathrm{C}$ higher than today [8]. The paleoprecipitations increased as a result of the end of the monsoon circulation [9]. In Argentina, the conchostracan bearing units as the Lagarcito Fm. (Lower Cretaceous) was interpreted as a deposit of a shallow and perennial freshwater lake in a semi-arid climate [10]. The Cañadón Calcáreo Fm. (Upper Jurassic - Lower Cretaceous) was referred by [11] to sequences represented swampy areas, with a rich and diverse conchostracan fauna in subtropical seasonal dry climate. In Brazil-Uruguay the units are, the Botucatu Fm = Tacuarembó Fm (Late Jurassic - Early Cretaceous), indicating desert climate [12]. The Santana Fm. (Lower Cretaceous) represent tropical climate with highly dependent on the rainfall in the mating epoch [13] was, favorable to establish "conchostracan" populations. The Bauru Basin (San Carlos Fm) the climate was hot and arid [14]. The climate was warm and very dry, probably desert [14].

\section{Conclusion}

Finally, the climatic characterization for the Cretaceous of South America, summarized as a warm climate with rainfall and marked seasonality, allowed the development of the "conchostracan" populations so far recorded.

\section{Acknowledgements}

This is a contribution to UNESCO-IUGS IGCP Project 679.

\section{Conflicts of Interest}

The authors declare no conflicts of interest regarding the publication of this paper.

\section{References}

[1] Wang, C., Feng, Z., Zhang, L., Huang, Y., Cao, K., Wang, P. and Zhao, B. (2013) Cretaceous Paleogeography and Paleoclimate and the Setting of SKI Borehole Sites in Songliao Basin, Northeast China. Palaeogeography, Palaeoclimatology, Palaeoecology, 385, 17-30. https://doi.org/10.1016/j.palaeo.2012.01.030

[2] Campbell, I.H. and Allen, C.M. (2008) Formation of Supercontinents Linked to Increases In: Atmospheric Oxygen. Nature Geoscience, 1, 554-558. https://doi.org/10.1038/ngeo259

[3] Holz, M. (2015) Mesozoic Paleogeography and Paleoclimates-A Discussion of the Diverse Greenhouse and Hothouse Conditions of an Alien World. Journal of South American Earth Sciences, 61, 91-107. https://doi.org/10.1016/j.jsames.2015.01.001

[4] Parrish, J.T. (1993) Climate of the Supercontinent Pangaea. The Journal of Geology, 101, 215-233. https://doi.org/10.1086/648217 
[5] Carvalho, I.S., Gasparini, Z.B., Salgado, L., de Vasconcellos, F.M. and da Silva Marinho, T. (2010) Climate's Role in the Distribution of the Cretaceous Terrestrial Crocodyliformes throughout Gondwana. Palaeogeography, Palaeoclimatology, Palaeoecology, 297, 252-262. https://doi.org/10.1016/j.palaeo.2010.08.003

[6] Iglesias, A., Artabe, A.E. and Morel, E.M. (2011) The Evolution of Patagonian Climate and Vegetation from the Mesozoic to the Present. Biological Journal of the Linnean Society, 103, 409-422. https://doi.org/10.1111/j.1095-8312.2011.01657.x

[7] Pierazzo E. (2009) Cretaceous/Tertiary (K-T) Boundary Impact, Climate Effects. In: Gornitz V., Ed., Encyclopedia of Paleoclimatology and Ancient Environments. Encyclopedia of Earth Sciences Series, Springer, Dordrecht, 3-52. https://doi.org/10.1007/978-1-4020-4411-3_52

[8] Compagnucci, R.H. (2011) Atmospheric Circulation over Patagonia from the Jurassic to Present: A Review through Proxy Data and Climatic Modelling Scenarios. Biological Journal of the Linnean Society, 103, 229-249. https://doi.org/10.1111/j.1095-8312.2011.01655.x

[9] Parrish, J.T. (1987) Global Palaeogeography and Palaeoclimate of the Late Cretaceous and Early Tertiary. In: Friis, E.M., Chaloner, W.G. and Crane, P.R., Eds., The Origin of Angiosperms and Their Ecological Consequences, Cambridge University Press, Cambridge, 51-73.

[10] Prámparo, M., Ballent, S., Gallego, O.F. and Milana, J.P. (2005) Paleontología de la Formación Lagarcito (Cretácico Inferior alto), provincia de San Juan, Argentina. Ameghiniana, 42, 93-114.

[11] Volkheimer, W., Quatroccio, M., Cabaleri, N.G., Narváes, P., Scafati, L. and Melendi, D. (2015) Environmental and Climatic Proxies for the Cañadón Asfalto and Neuquén Basins (Patagonia, Argentina). Review of Middle to Upper Jurassic Continental and Near Coastal Sequences. Revista Brasileira de Paleontología, 18, 71-82. https://doi.org/10.4072/rbp.2015.1.04

[12] do Amarante, F.B., Scherer, C.M., Aguilar, C.A.G., dos Reis, A.D., Mesa, V. and Soto, M. (2019) Fluvial-Eolian Deposits of the Tacuarembó Formation (Norte Basin-Uruguay): Depositional Models and Stratigraphic Succession. Journal of South American Earth Sciences, 90, 355-376. https://doi.org/10.1016/j.jsames.2018.12.024

[13] Martins-Neto, R.G., Ribeiro-Júnior, C. and Prezoto, F. (2005) New Fossils (Isoptera: Hodotermitidae), from the Santana Formation (Lower Cretaceous, Araripe Basin, Northeast Brazil), with Descriptions of New Taxa Including a New Subfamily. Sociobiology, 47, 1-10.

[14] Suguio, K. and Barcelos, H. (1983) Calcretes of the Bauru Group (Cretaceous), Brazil: Petrology and Geological Significance. Boletim IG, 14, 31-47.

https://doi.org/10.11606/issn.2316-8978.v14i0p31-47 